\author{
Research Article \\ www.ijrap.net
}

\title{
BASICS FOR THE DEVELOPMENT OF PROTOTYPE RESEARCH SOFTWARE RELEVANT TO INFANTS' PRAKRITI ASSESSMENT FOR VIKRITI MANAGEMENT AND POSSIBLE FUTURE DISORDERS
}

Srivastava Niraj ${ }^{1 *}$, Singh Praguna ${ }^{2}$, Gehlot Sangeeta ${ }^{3}$, Singh Sanjay ${ }^{4}$, Singh B.M. ${ }^{5}$

${ }^{1} \mathrm{PhD}$ Scholar, Department of Kaumarbhritya/Balroga, Faculty of Ayurveda, IMS, BHU, Varanasi, India

${ }^{2}$ Final year student (B.Tech. Computer Science), MIT, Manipal, Karnataka, India

${ }^{3}$ Department of Kriya Sharir, Faculty of Ayurveda, IMS, BHU, Varanasi, India

${ }^{4}$ Department of Computer Science, IIT, BHU, Varanasi, India

${ }^{5}$ Department of Kaumarbhritya/Balroga, Faculty of Ayurveda, IMS, BHU, Varanasi, India

Received on: 02/01/17 Accepted on: 20/02/17

*Corresponding author
E-mail: nirajimsbhu@gmail.com, praguna14@gmail.com

DOI: 10.7897/2277-4343.08139

\begin{abstract}
Prakriti (physical and mental constitution) is a unique and one of the basic concepts of Ayurveda that explains the individuality. It is decided at the time of conception, and subsequently nourished during the intrauterine life. A careful assessment of Prakriti after excluding similar Vaikrit features and consideration of various Prakriti influencing factors not only takes lot of time but also needs good memory. This study was planned to project the concept and stepwise methodology essential for the development of PRS-IPA software to save the time, reutilization of stored data for individualized management and prevention of forthcoming disorders. Platform used for the development of the software is Microsoft Visual Basic 2010, Express Edition, which is a part of Visual Studio 2010 package, while the Microsoft excel sheet 2007 is used for the storage of data. Clicking 'About Software' button on homepage displays the details about the software viz. basic structure of software, minimum system requirements and operational guidelines for the users/research scholars. Clicking Submit button leads us to the actual software. The developed software is a complete package for helping users/pediatricians in analyzing infants' Prakriti. It also assists in differentiating physiological features from the pathological features through basic analysis for writing the management and forecast the possibility of future disorders. The result of data shall be very expedient in developing more efficient and accurate infant's Prakriti labelling advance software by the research scholars.
\end{abstract}

Keywords: Prakriti, Infants, PRS-IPA (Prototype Research Software for Infants' Prakriti Assessment)

\section{INTRODUCTION}

At the present time, many centuries' old Ayurvedic concepts are being brought to use in all parts of the world. One such Ayurvedic concept is Prakriti determination and after differentiating from the Vikriti, it can be used for diagnosis ${ }^{1}$, management of disease ${ }^{2}$ and forecast the proneness for future disorders ${ }^{3}$. Knowledge of Prakriti can guide the parents also for prevention ${ }^{4}$ of expected disorders in their children.

Prakriti is a unique, but definite unchangeable traits manifested in persons and individualize them. This is mainly decided by a permanent configuration of Dosha at the time of conception and differs individual to individual. These specific types of Doshika Prakriti can be identified in growing individuals ${ }^{5}$.

The word Prakriti means constitution ${ }^{6}$ and referred in many contexts, while the Vikriti is a Vikara (pathological manifestation $)^{7}$, a change of nature, alteration or deviation from any natural state of body or mind ${ }^{8}$. It is very clear that when Tridosha quantitatively or qualitatively are not in perfect state of equilibrium in the body may present various abnormal clinical features termed as Vaikrita Dosha and finally lead to Vikara in the body ${ }^{10}$. It is well-established concept that an individual of single Dosha Prakriti frequently falls sick i.e. more vulnerable to various diseases, while Samyawastha (equilibrium state) of Tridosha in an individual result in healthy state ${ }^{11}$.
The knowledge about the Prakriti is prerequisite for the assessment of Vikriti (pathology) hence it plays a very important role in deciding diagnosis, therapeutics and prognosis ${ }^{12}$.

So, the purpose of this research software is to project the concept and step wise methodology which is essential for the assessment of Prakriti of infants.

The objectives of this design are-

1. To ease the stress of Kaumarbhritya expert (Paediatrician) in determination of Prakriti of infants after differentiating analogous Vaikrita features for individualized management and prevention of forthcoming Prakriti prone disorders.

2. To ease the user's stress during recording and storage of data of healthy infants at registration and on subsequent follow ups.

3. To create infants' record database using excel (MS office) and other auxiliary facilities

\section{MATERIALS AND METHODS}

Platform used for development of the software is Microsoft Visual Basic 2010, Express Edition, which is a part of Visual Studio 2010package and can run in higher version too.

The components and various methods ${ }^{13,14,15-23}$ used for developing the software are: 
Microsoft Visual Basic 2010 Express Edition

It is used as the platform for development of the software. All the forms that are part of the software were created on Visual Basic 2010 using various tools present in the 'Express edition'.

\section{Microsoft Excel 2007 or any Higher Version}

Microsoft Excel is used for storing the data entered about the patient. The data about a patient is stored in various excel files in a sorted manner. Each detail about the patient is stored in separate columns of particular sheet.

Basic knowledge of Kaumarbhritya (Pediatric) subject

The data entry and analysis are the essential parts of the software. The user must have basic pediatric knowledge specific to Prakriti and Vikriti. Kaumarbhritya expert (Pediatrician) is recommended for data entry and analysis.

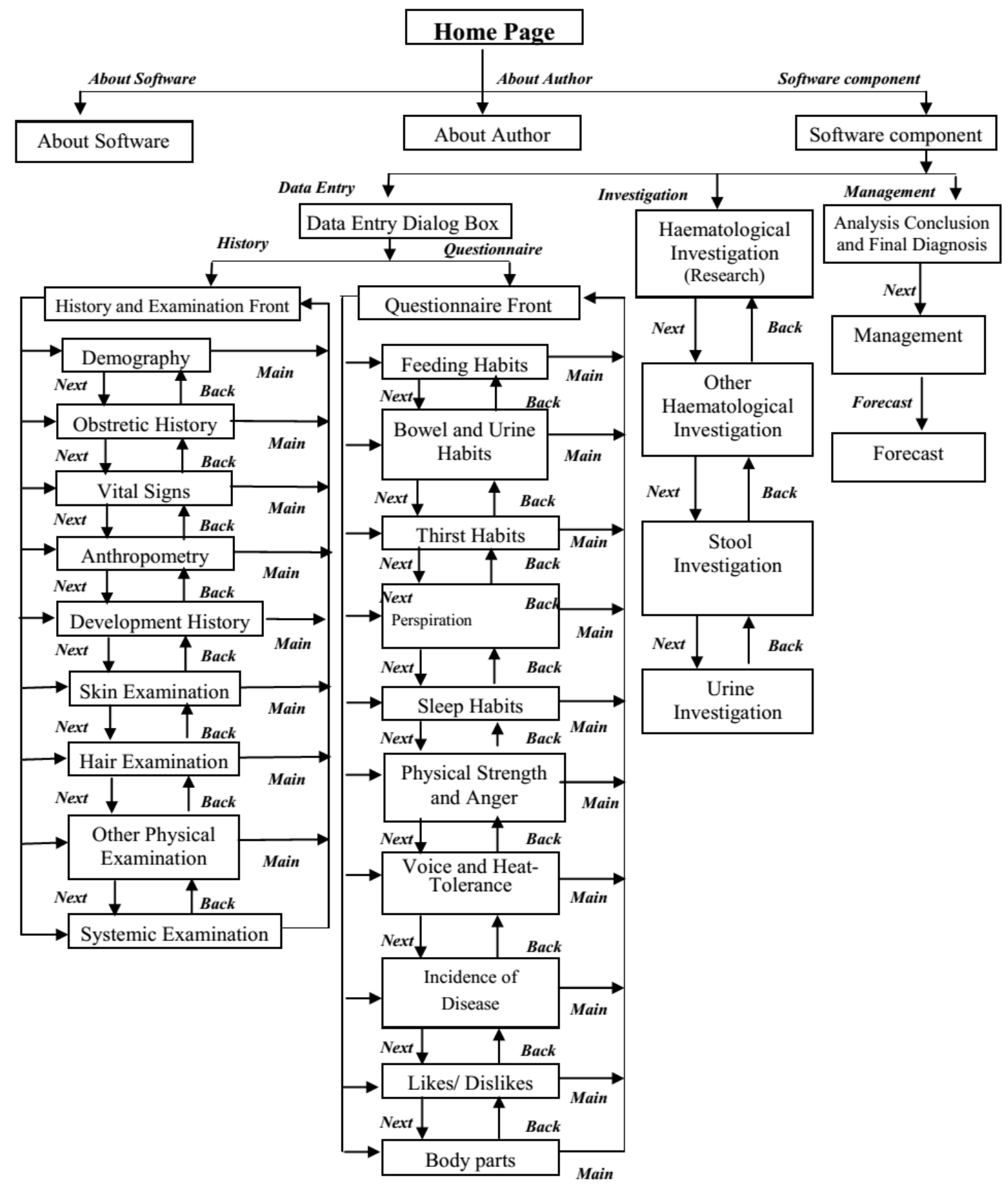

Flow diagram 


\section{STRUCTURE OF SOFTWARE}

The structure of the software can be divided into three basic parts:

\section{Data entry}

This part is used for entry of data which is used later by succeeding sections of the software. Entry of data is done by filling up details of the patient in specific fields corresponding to each label.

\section{Storage}

The details entered in the data entry part are stored in excel files which contain either 3 or 4 sheets so that details specific to each form can be stored in separate sheets, which are used in the analysis part.

\section{Analysis}

Data, stored in excel files are then used for analysis; thereafter analyzed data is used in management and forecast. The analysis is done through grading of the information present in the excel sheets using various pediatric parameters.

\section{DETAILED WORKING PLAN}

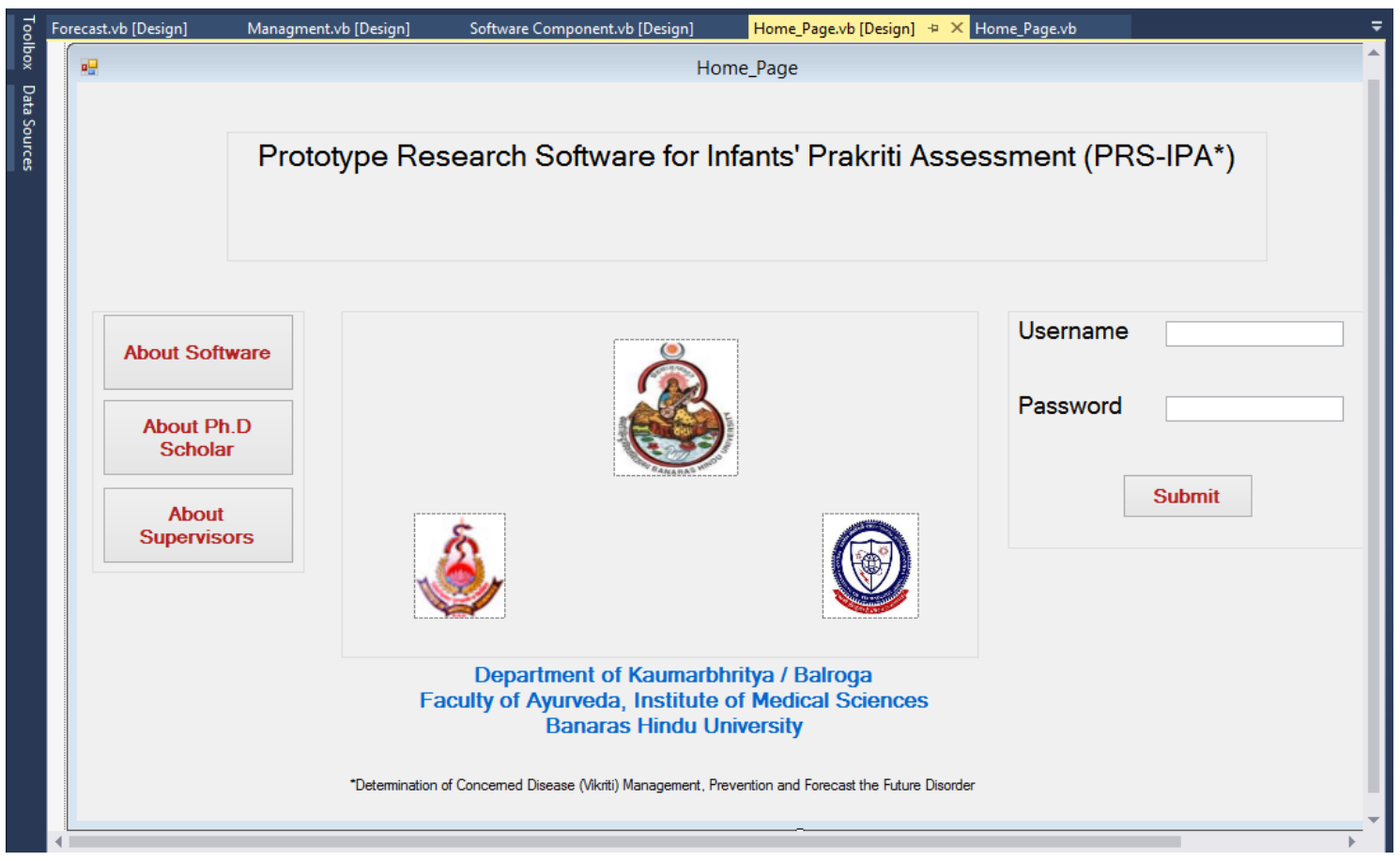

\section{Figure 1: Homepage}

When the software is run, first of all the homepage will be displayed. As shown in Figure 1, homepage has four buttons namely: one for About Software, two for authors which include About PhD Scholar and About Supervisors, and one for Submit button. Clicking on 'About PhD Scholar and 'About Supervisor' button displays a form which contains all the details about the PhD scholar and supervisors. Clicking 'About Software' button displays a form containing details about the software and the minimum system requirements for the software. Clicking Submit button leads us to the actual software.

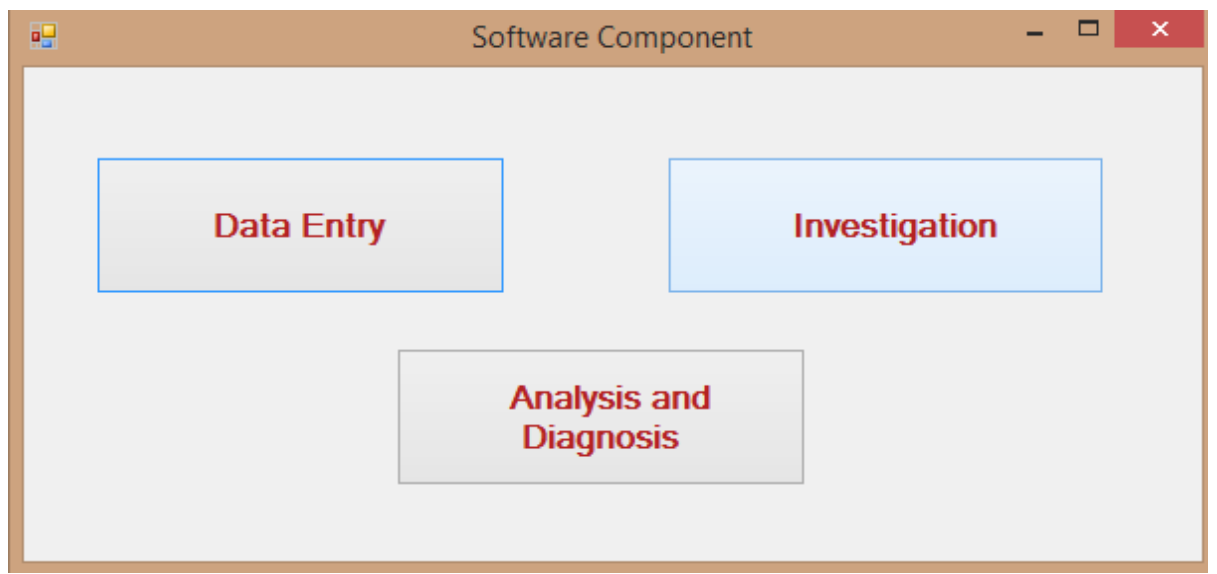

Figure 2: Software Component 
As an attempt to restrict the usage of the software to legitimate users the homepage requires an entry of correct login ID password combination when Submit button is pressed. If the login ID - password combination is incorrect then an error message is shown which displays that the login ID - password combination entered is not correct and only homepage is accessible unless correct combination is entered. If the login ID - password combination is correct, then 'Software Component' form is opened as shown in Figure 2. Software Component form has three main buttons: Data Entry, Investigations and Analysis. Clicking on 'Data Entry' button opens forms for entering data (basic pediatric information) about the patients. Clicking on 'Investigations' button leads to form used for entering the investigation details about the patients. Clicking on 'Analysis' button leads to Analysis form which displays all the details about the patient, once patient ID is entered.

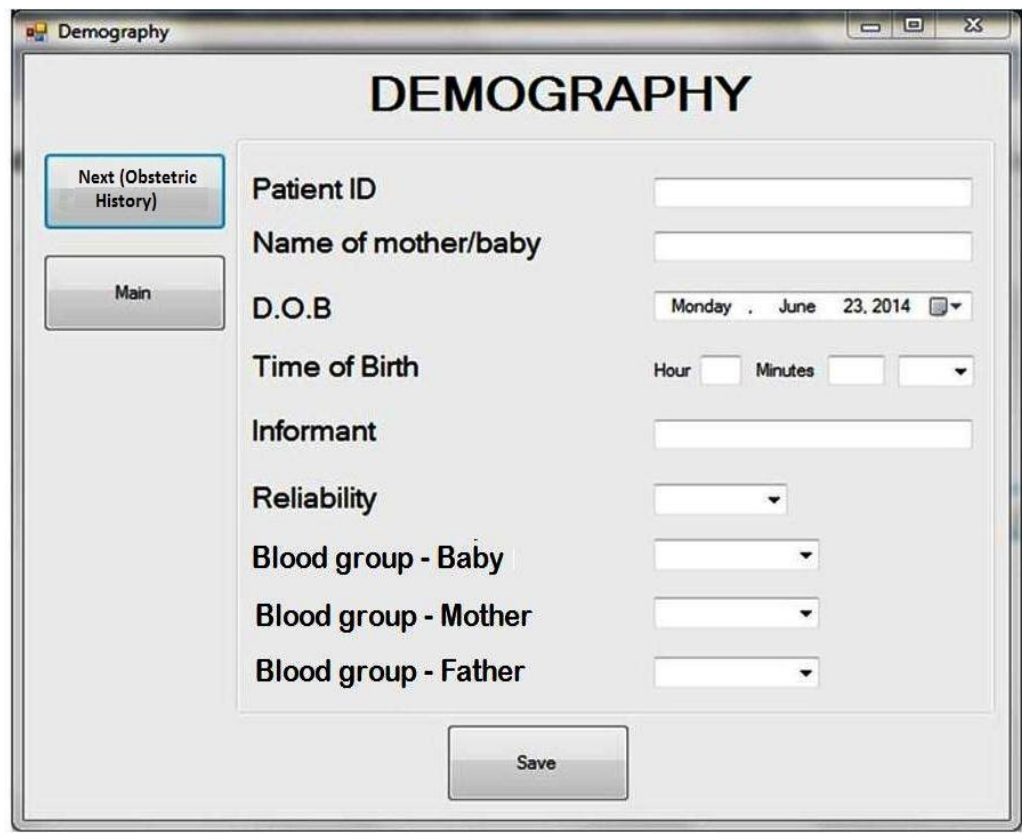

Figure 3: Demography

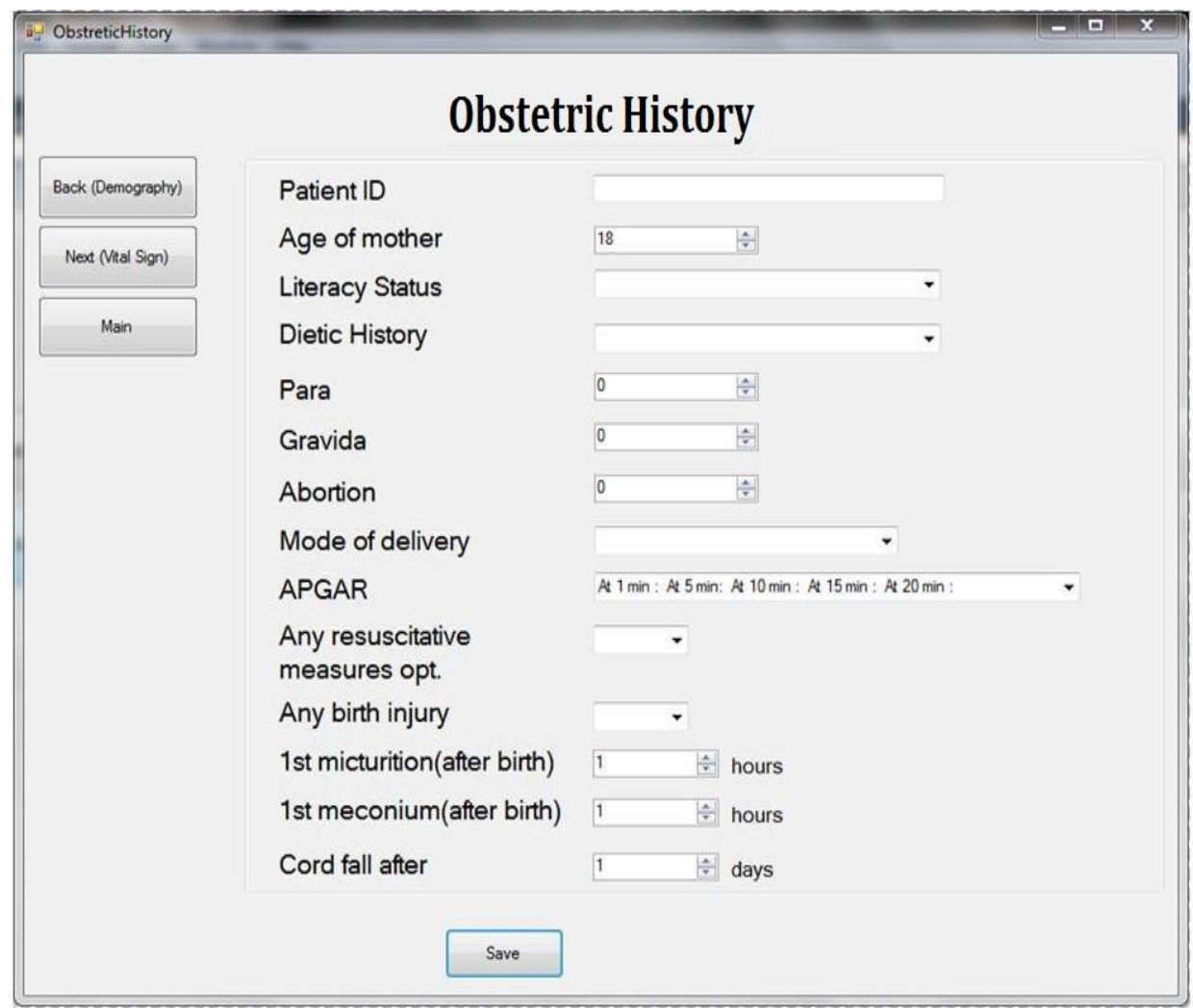

Figure 4: Obstetric History 
Data entry form has two options: History Basis and Questionnaire Basis, both of which lead to forms for entering data about the patient on their respective basis. History basis has 9 forms and Questionnaire basis has 10 forms respectively for data entry. History basis option leads to 'History Front' form which has buttons for all its data entry forms. Similarly, Questionnaire basis option leads to 'Questionnaire Front' which has button for all its data entry form. All the forms present within History Front and Questionnaire front have a 'Main button' to lead them back to their parent forms. Also, all the forms are interconnected with Next and Back buttons. Investigation option is also used for entering data about the patient related to the investigations.

The forms shown in Figure 3 and 4 are present within History basis data entry and they can be considered as examples of all the forms for data entry.

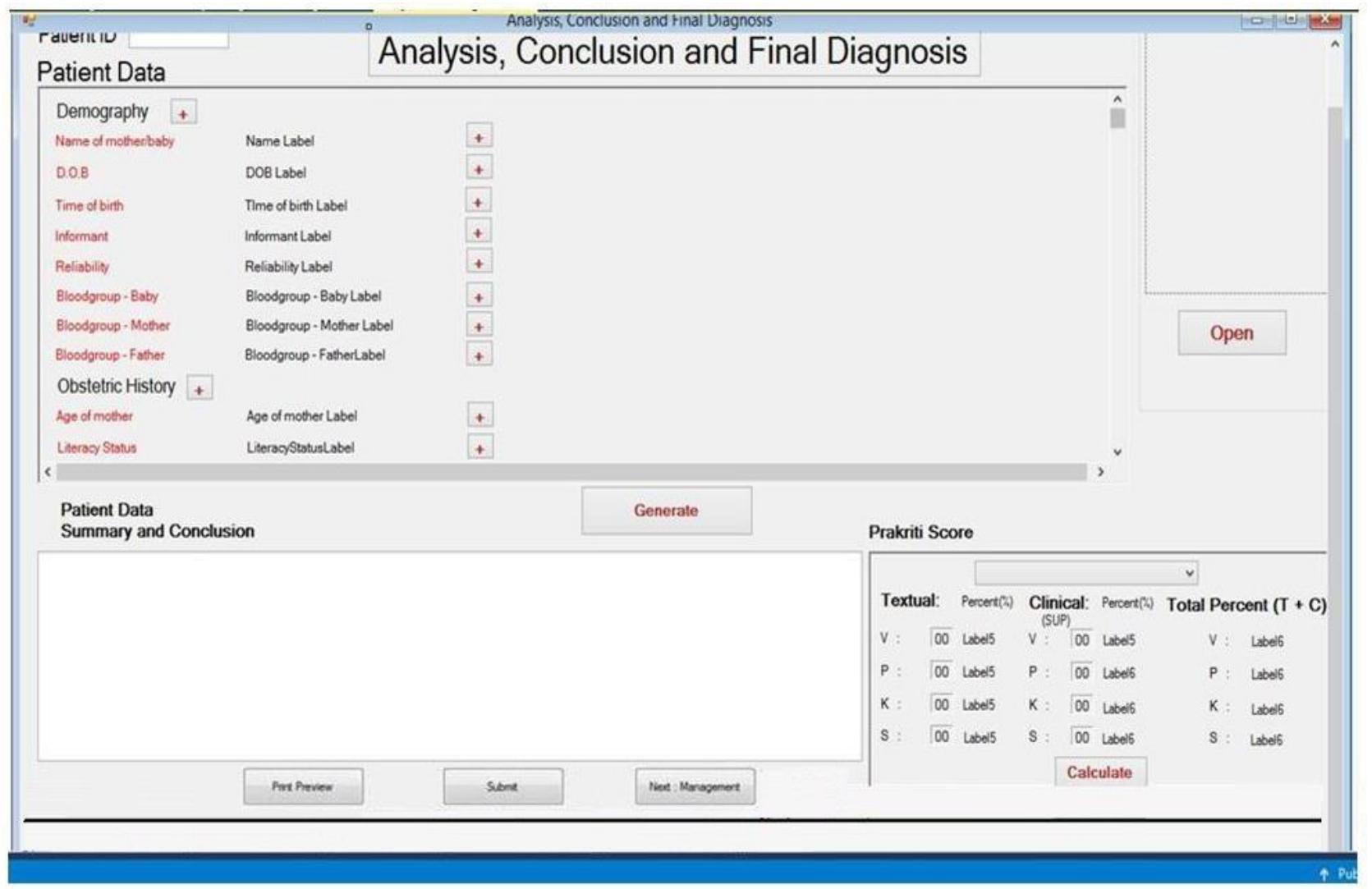

Figure 5: Analysis

Once all the details have been entered through data entry and investigation then Analysis can be done. The 'Analysis' form, as shown in Figure 5, has a panel displaying all the labels representing all the data entries called 'Patient Data Summary'. All the data entries also have a ' + ' button in front of them so as to select them to transfer the particular data onto management page. This form also has a textbox which is used by the users for writing the conclusion. Another panel present on the same form can be used for displaying the Prakriti of the patient derived from the details entered in the questionnaire. When the submit, button is pressed then all the selected data entries along with the conclusion are transferred to their respective textboxes on the management page. 'Analysis' page also has a print button which leads to the print preview for printing the 'Patient Data Summary' and Conclusion.

When Management form (as shown in Figure 6) is opened the textbox for Patient Data Summary and Conclusion are filled up from the data of Analysis page. This form also has three textboxes for entering Preventive measures, Curative treatment and Prognosis. The 'Forecast' button leads to "Forecast form" which has textboxes for Analysis data and Management data which are used by the user for writing forecast for the patient.
Forecast form (as shown in Figure 7) also has a print option similar to the Analysis form.

\section{RESULT AND DISCUSSION}

The software developed is a complete package aimed at helping users (pediatricians) in analyzing Prakriti of infants and also assist in differentiating the physiological features from the pathological features through basic analysis for writing the management and forecast for the pediatric population. Analysis about the Prakriti, Vikriti, Desha, Kala, food habits, and habitats etc. of patients will be valuable in planning treatment and knowing possible forthcoming disorders. Knowledge of Prakriti (Personality) of an infant will guide the parents in deciding the career of their wards at a very early age.

The developed prototype software is a complete package which utilizes Microsoft Visual Basic 2010 Express and Microsoft Excel. Visual Basic is used as a platform for creating and working with the forms. Microsoft Excel is used for details of the patient. The forms of the software are used for input of details, storage of details into excel sheets and analysis by retrieving the details stored in the excel sheets. These stored data including analysed data shall be available as quick reference for 
the research scholar, which can be used for deciding the reference range of different objective parameters selected for conforming subjective parameters. The result of data shall be very expedient in developing more efficient and accurate infant's Prakriti labelling advance software.

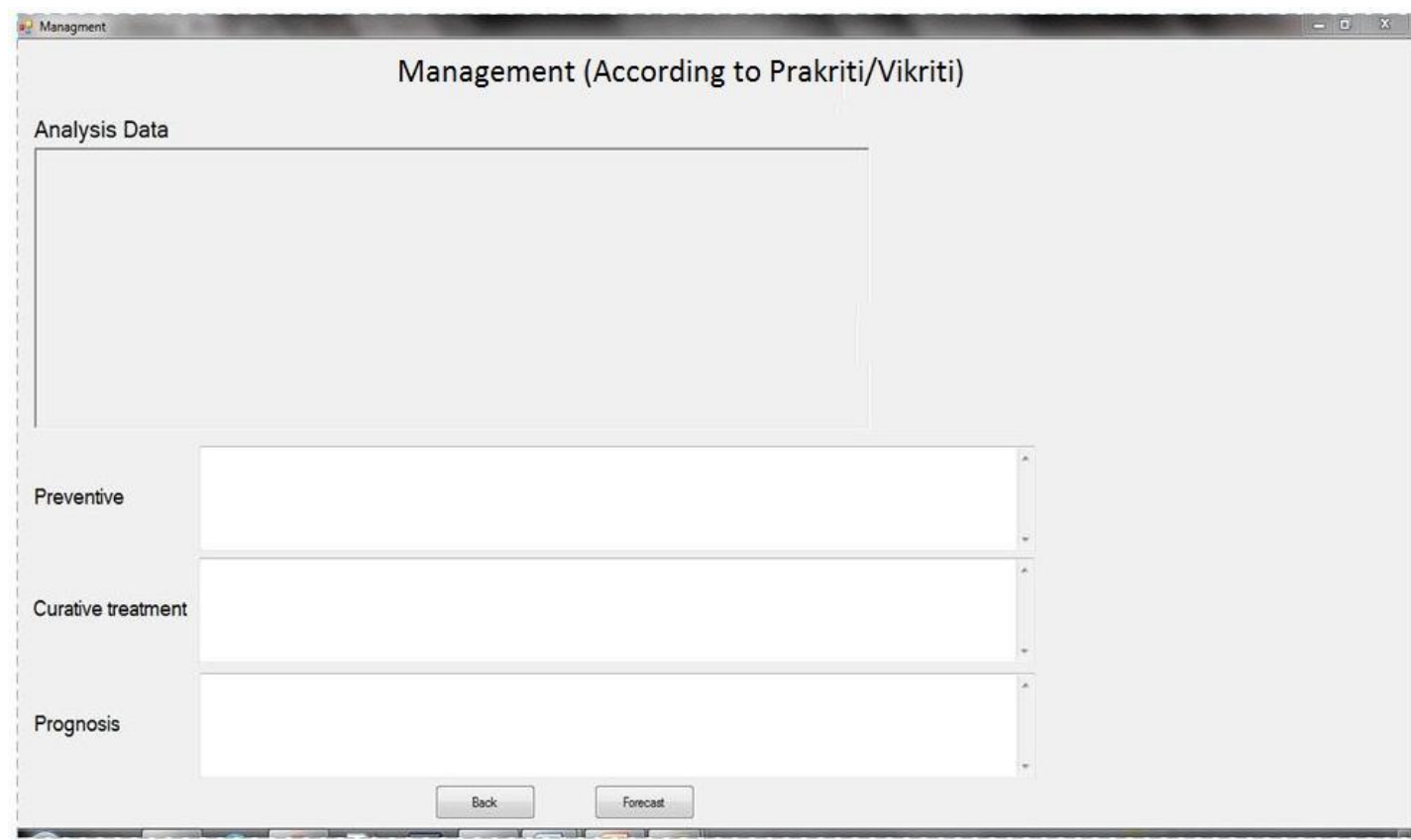

Figure 6: Management

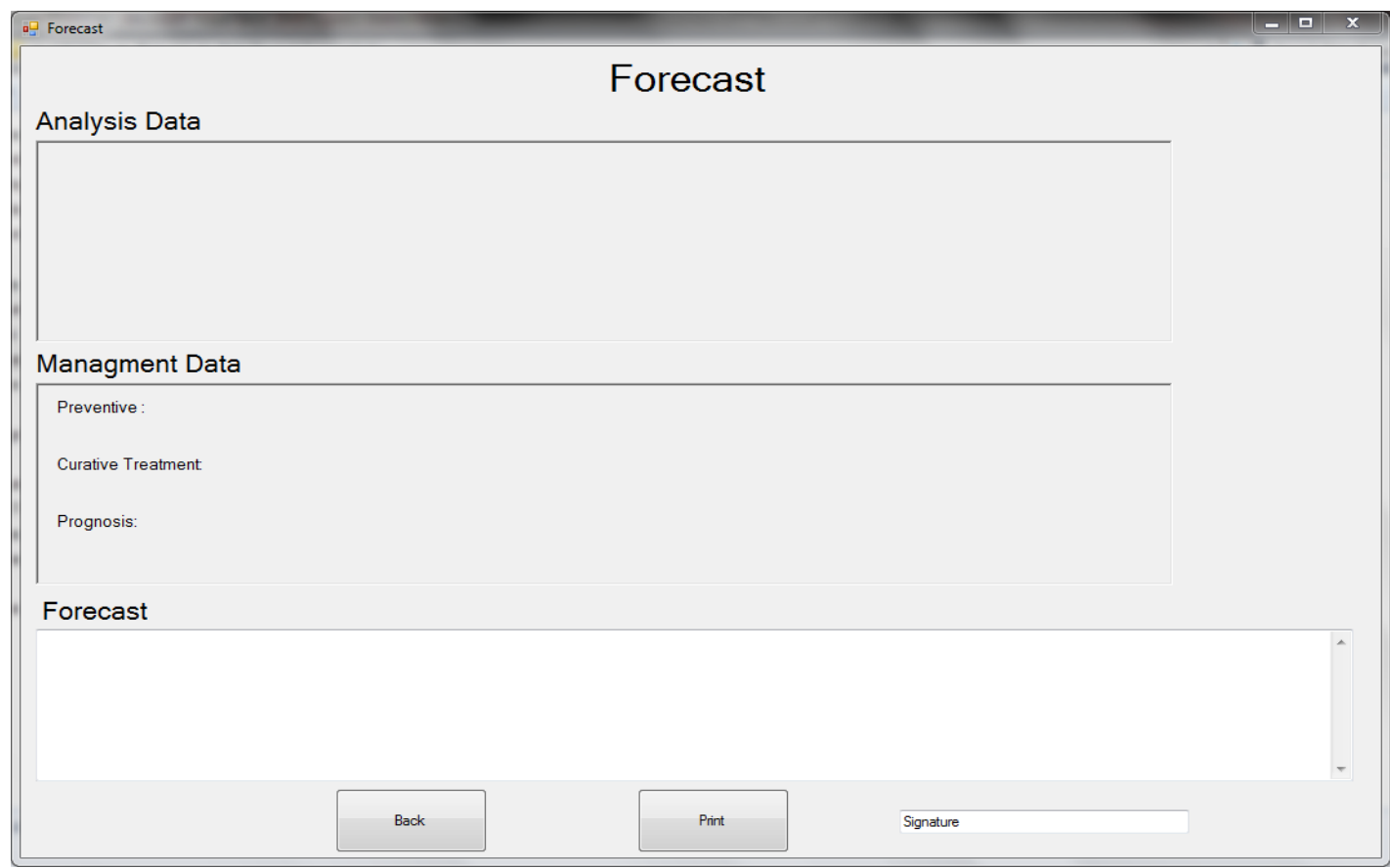

Figure 7: Forecast

\section{CONCLUSION}

The developed software shall provide a platform for the collection of data systematically, Prakriti determination after differentiating similar features found in Vaikrit conditions and basic data-analysis. This software will be also helpful in analysis of Prakriti of an infant based on the entered data, ensure the easier planning for individualized management and forecast the possibility of Prakriti dependent diseases in future. Printing of stored/saved data is also facilitated in PRS (Prototype Research Software). The designed software (PRS-IPA*) shall be helpful in augmenting the efficiency of Kaumarbhritya expert (Paediatrician) for Prakriti assessment.

This prototype software can be used as a basis for future developments and researches in the same field. This software model can be used as a base for analysis of Prakriti and Vikriti for adults after minor modification as per the specific characteristics of Prakriti developed in the adult only. 


\section{ACKNOWLEDGEMENT}

Authors are grateful to Prof. V.K. Joshi, Department of Dravyaguna, IMS, BHU, Dr. Girish Singh, Statistician, Department of Community medicine, IMS, BHU; Mr. Srikant (PhD Scholar from department of Computers science IIT BHU), Mr. Abibi Ali (PhD Scholar from department of Computers science IIT BHU) and Mr. Sundaram Mishra 2nd year student (B.Tech) NIT (Ranchi), Jharkhand for the guidance and support in software development.

\section{REFERENCES}

1. Agnivesha, Charaka, Dridhabala, Charaka Samhita, Vimansthan 6/16, 7/4, edited by Vaidya Jadavaji Trikamji Acharya.Varanasi: Chaukhambha Surabharati Prakashana; 2008.

2. Agnivesha, Charaka, Dridhabala, Charaka Samhita, Sutra Sthana, 10/11, edited by Vaidya Jadavaji Trikamji Acharya.Varanasi: Chaukhambha Surabharati Prakashana; 2008

3. Vagbhatta, Ashtanga Hridayam, Sutrasthan $1 / 10$, edited by Anna Moreshwar Kunte. Varanasi: Chaukhamba Sanskrita Pratishthan 2009.

4. Agnivesha, Charaka, Dridhabala, Charaka Samhita, Sutra Sthana, 7/4, edited by Vaidya Jadavaji Trikamji Acharya.Varanasi: Chaukhambha Surabharati Prakashana; 2 008.

5. Agnivesha, Charaka, Dridhabala, Charaka Samhita, Viman Sthana, 8/95, edited by Vaidya Jadavaji Trikamji Acharya, Varanasi: Chaukhambha Surabharati Prakashana; 2008.

6. Monier Williams, Sanskrit English dictionary, Motilal Banarasidas Publication 2002;654.

7. Agnivesha, Charaka, Dridhabala, Charaka Samhita, Viman Sthana, 8/101, edited by Vaidya Jadavaji Trikamji Acharya.Varanasi: Chaukhambha Surabharati Prakashana; 2 008.

8. Monier Williams, Sanskrit English dictionary, Motilal Banarasidas Publication 2002;954.
9. Agnivesha, Charaka, Dridhabala, Charaka Samhita, Sutra Sthana, 7/3940, edited by Vaidya Jadavaji Trikamji Acharya.Varanasi: Chaukhambha Surabharati Prakashana; 2 008.

10. Srivastava N, Gehlot S, Singh S, Singh BM. Application of different parameters for selecting normaland abnormal skin characteristics in determination of Prakriti in infants. Int. J. Res. Ayurveda Pharm. 2015:6(2):161-168 http://dx.doi.org/10.7897/2277-4343.06232

11. Agnivesha, Charaka, Dridhabala, Charaka Samhita, Sutrasthana,10/11-13, edited by Vaidya Jadavaji Trikamji Acharya.Varanasi: Chaukhambha Surabharati Prakashana; 2 008 .

12. Agnivesha, Charaka, Dridhabala, Charaka Samhita, Sutrasthana, 7/3940, edited by Vaidya Jadavaji Trikamji Acharya.Varanasi: Chaukhambha Surabharati Prakashana; 2 008.

13. Halvorson, Michael 2010. Microsoft Visual Basic 2010 Step by Step. Microsoft Press, 2010

14. Mayo, Joe. Beginner's Guide Visual Studio. ISBN 13: 9780071668958. Publisher: Mc GrawHill Education, 2010.

15. Tylee, Lou. Learn Visual Basic 6.0.KID ware, 1998. http://www.kidwaresoftware.com/index.htm

16. https://i-msdn.sec.s-msft.com

17. http://stackoverflow.com/

18. http://cdn.dreamincode.net/home/images/logo_2012.gif?v=3

19. https://www.codeproject.com/

20. https://support.microsoft.com/\#

21. http://www.developerfusion.com/

22. https://in.answers.yahoo.com/

23. http://www.vb-helper.com/index.html

\section{Cite this article as:}

Srivastava Niraj et al. Basics for the development of prototype research software relevant to infants' Prakriti assessment for vikriti management and possible future disorders. Int. J. Res. Ayurveda Pharm. 2017;8(Suppl 1):57-63 http://dx.doi.org/ $10.7897 / 2277-4343.08139$

Disclaimer: IJRAP is solely owned by Moksha Publishing House - A non-profit publishing house, dedicated to publish quality research, while every effort has been taken to verify the accuracy of the content published in our Journal. IJRAP cannot accept any responsib ility or liability for the site content and articles published. The views expressed in articles by our contributing authors are not necessarily those of IJRAP editor or editorial board members. 